\title{
Development of a Rapid Immunodiagnostic Test for Pork Components in Raw Beef and Chicken Meats: a Preliminary Study
}

\author{
S. N. Depamede \\ Microbiology and Biotechnology Laboratory, Faculty of Animal Science, Mataram University \\ Jln. Majapahit No. 62 Mataram, NTB, 83125, Indonesia \\ (Received 30-05-2010; accepted 25-05-2011)
}

\begin{abstract}
ABSTRAK
Metode uji cepat imunodiagnostik untuk memastikan adanya cemaran komponen daging babi pada daging sapi dan daging ayam mentah telah berhasil dikembangkan pada penelitian ini. Prinsip pengembangan imunodiagnostik ini adalah dengan mengkonjugasikan koloid emas sebagai penanda dengan antibodi poliklonal IgG babi. Konjugat ini diletakkan pada bantalan konjugat, salah satu bagian dari sistem "strip tes" imunokromatografi. Strip tes yang dihasilkan kemudian digunakan untuk uji ada tidaknya cemaran komponen daging babi. Ekstrak campuran daging mentah yang digiling halus dalam bufer garam fosfat, berupa campuran daging babi/daging sapi atau daging babi/daging ayam dalam perbandingan 1/0;1/100;1/1000;1/5.000; 1/10.000 (berat/berat) digunakan pada studi pendahuluan dalam skala laboratorium. Sebagai kontrol digunakan ekstrak daging sapi dan daging ayam mentah, tanpa campuran daging babi sama sekali. Hasil penelitian menunjukkan bahwa dalam waktu 10 menit cemaran komponen daging babi dapat dideteksi secara kasat mata pada campuran 1 bagian daging babi per 5.000 bagian daging sapi atau daging ayam mentah, bahkan pada campuran 1/10.000 masih dapat terdeteksi. Tes immunodiagnostik ini dapat diterapkan untuk mendeteksi dengan mudah komponen daging babi pada produk olahan daging sapi atau daging ayam mentah. Perlu dilakukan penelitian lebih lanjut untuk pengembangan skala komersial.
\end{abstract}

Kata kunci: pencemaran daging, imunodiagnostik, daging babi, uji cepat

\begin{abstract}
A rapid immunodiagnostic test that provides visual evidence of the presence of pork components in raw beef and chicken meats was developed. Colloidal gold was prepared and conjugated with anti-Swine IgG polyclonal antibody. Immunochromatographic test strips were produced, and then were used to test laboratory adulterated raw meat samples. The samples consisted of pork-inbeef, or pork-in-chicken at 1/0;1/100;1/1,000;1/5,000;1/10,000 (w/w) adulteration levels that were extracted in phosphate-buffered saline. Raw beef and chicken meats without pork were included as controls. Analysis was completed in $10 \mathrm{~min}$. Detection limit was 1/5,000 (w/w), although 1/10,000 was also observed. This immunodiagnostic tests can be conveniently applied to detect low levels of pork components in raw beef and chicken meat products. For the commercial purposes, further studies need to be carried out.
\end{abstract}

Key words: adulteration meat, immunodiagnostic, pork, rapid test

\section{INTRODUCTION}

An effective method for detecting pork in food is essential in order to avoid fraudulent or unintentional adulteration of food. For some reasons, people restrict pork from their diet. In the view of some religions, such as Islam and Judaism, pork and diet or foods containing pig components are serious matters. In Islam, such

\footnotetext{
* Corresponding author:

sulaiman_n@unram.ac.id
}

foods are categorized haram (unlawful or prohibited) for Muslims to consume (Aida et al., 2005). Other people have concerns regarding health and food safety including reasons such as allergies to pork (Asero et al., 1997).

In some countries, where the price of pork is cheaper than beef or chicken meats, it is a common practice for irresponsible retailers to mix pork into beef or chicken meats. For these reasons, effective analytical methods for detecting meat adulteration are crucial for law enforcement and consumer protection (Ballin et al., 2009). A wide variety of analytical methods for 
the determination of pig components in foods or diet have been described. These include, methods based on electrophoresis (Kim \& Shelef, 1986), isoelectric focusing (Jaussen et al., 1990), chromatography (Saeed et al., 1989), enzyme-linked immunosorbent assay (ELISA) (Hsieh et al., 1996; Chen et al., 1998; Macedo-Silva et al., 2000; Ofori \& Hsieh, 2007; Asensio et al., 2008), electronic nose and gas chromatography mass spectrometer with headspace analyzer (GCMS-HS) (Nurjuliana et al., 2011), also fourier transform infrared (FTIR) spectroscopy (Rohman et al., 2011). In addition to those methods, methods based on DNA technology such as DNA hybridization (Ebbehøj \& Thomsen, 1991; Ballin et al., 2009), polymerase chain reaction (PCR) (Matsunaga et al., 1995; Rensen et al., 2006; Rojas et al., 2009; Ballin et al., 2009; Rojas et al., 2010) have been used for more than two decades. Furthermore Aida et al. (2005 \& 2007) have developed a method for species identification from pork and lard samples using PCR analysis of a conserved region in the mitochondrial (mt) cytochrome $b$ (cyt $b$ ) gene. Recently a pig-specific SYBR green I real-time PCR assay has also been developed (Farrokhi \& Joozani, 2011).

The DNA based-approach was found to be highly sensitive, but the assay relies on a sophisticated amplification system. It needs specialised laboratory equipment and well trained personnel. The developed methods mentioned above are useful for confirmation or verification test purposes. However for screening and analysing a large quantity of samples in the field, it is important to investigate cost effective and practical assay methods. These types of assays must be robust and easy to perform.

Lateral-flow assays, which to date have been used as diagnostic tools for monitoring drugs (Wong, 2002), toxins (Yeoh \& Sun, 2001; Bazin et al., 2010), hormones (Henderson \& Stewart, 2000), assays for the environmental pollutants (Aveyard et al., 2008), and pathogens (Ketema et al., 2001; Brandonisio et al., 2002; Hara et al., 2008; Ngom et al., 2010) allow rapid, qualitative determination of analytes. This technique is based on an immunochromatographic procedure that utilizes antigen-antibody reaction on a nitrocellulose membrane, which is indicated by a color band from attached gold particles. There are several advantages of the lateralflow assay method as it provides a rapid test period (less than $15 \mathrm{~min}$ ) to get results, long-term stability over a wide range of climates and is relatively inexpensive to produce (Khamrin et al., 2009; Zhi et al., 2010). These characteristics enable this test to be ideally suited for onsite testing by untrained personnel without using specialized equipment. A high-affinity anti-Swine IgG polyclonal antibody was evaluated to develop a userfriendly, rapid, and sensitive immunochromatographic (IC) assay for detecting of low levels of porcine content in raw beef and chicken meats.

\section{MATERIALS AND METHODS}

\section{Materials}

Meat samples from beef, chicken, and pig were used. In this study pure beef and chicken samples were used as controls. The samples were purchased from a traditional market in Mataram, Lombok, West Nusa Tenggara, Indonesia.

Sodium chloride $(\mathrm{NaCl})$, sodium phosphate dibasic anhydrous $\left(\mathrm{Na}_{2} \mathrm{HPO}_{4}\right)$ and sodium phosphate monobasic anhydrous $\left(\mathrm{NaH}_{2} \mathrm{PO}_{4}\right)$, citric acid, brij 35, and gold chloride were obtained from Sigma (St. Louis, MO, USA). Tris- $\mathrm{HCl}$ and sodium azide were purchased from Merck (USA). Sample pad, the conjugate release pad, the analytical (nitrocellulose) membrane and the absorbent pad were obtained from Advanced Microdevices Pvt, Ltd., India.

Affinity purified antibody to swine $\operatorname{IgG}(\mathrm{H}+\mathrm{L})$ produced in goat was obtained from KPL (USA). Bovine serum albumin (BSA) was purchased from Sigma (St. Louis, MO, USA). Goat anti-mouse IgG (GAM) antibody was obtained from Arista Biological Inc., USA. All solvents and other chemicals were analytical reagent grade.

Preparation of colloidal gold. Colloidal gold was prepared based on Kim et al. (2007) with several modifications. Five millilitres of a $1 \%(\mathrm{w} / \mathrm{v})$ stock solution of hydrogen tetrachloroaurate trihydrate was added to 500 $\mathrm{ml}$ of distilled water and heated to boiling point. Five millilitres of a freshly made $1 \%$ solution of sodium citrate was added to the gold solution under constant stirring and the mixture was boiled until it turned red. After an additional $5 \mathrm{~min}$ boiling, the solution was cooled to 4 ${ }^{\circ} \mathrm{C}$ for further processing.

Preparation of colloidal gold probe. Colloidal gold was used for conjugation of IgG. Affinity purified goat-anti Swine polyclonal antibody $(2 \mathrm{ml}, 0.5 \mathrm{mg} / \mathrm{ml}$, in $5 \mathrm{mM}$ Tris- $\mathrm{HCl}, \mathrm{pH} 7.5)$ was added to $20 \mathrm{ml} \mathrm{pH}$-adjusted colloidal gold solution and was agitated for $30 \mathrm{~min}$. Then $2 \mathrm{ml}$ of $1 \%(\mathrm{w} / \mathrm{v})$ BSA solution was added and was agitated for another $15 \mathrm{~min}$. The mixture was centrifuged at $4,800 \times g$ for $30 \mathrm{~min}$. After centrifugation, the gold pellets were dissolved in $50 \mathrm{mM}$ Tris/ $\mathrm{HCl}$ buffer.

Preparation of immunochromatographic test strips. The sample/conjugate pad was treated with $50 \mathrm{mM}$ borate buffer, $\mathrm{pH} 7.4$, containing 1\% BSA, 0.5\% Tween20 , and $0.05 \%$ sodium azide, and dried in a controllable drying chamber (Heraeus Instruments, USA) at $60{ }^{\circ} \mathrm{C}$ for $60 \mathrm{~min}$ (modified from Kim et al. 2007). Goat antiSwine polyclonal antibody-BSA $(0.020 \mathrm{mg} / \mathrm{ml})$ and goat anti-mouse antibody $(1.000 \mathrm{mg} / \mathrm{ml})$ were applied to the nitrocellulose membrane as the test and control lines, respectively, using Isoflow dispenser (Imagine Technology, USA), and dried in a controllable drying chamber (Heraeus Instruments, USA) at $35{ }^{\circ} \mathrm{C}$ for 60 min.

An absorption pad was used without treatment. The colloidal gold probe was applied to a glass-fiber membrane treated with brij and completely dried at $35{ }^{\circ} \mathrm{C}$. The nitrocellulose membrane, absorption pad, glass fiber membrane, and pretreated sample pad were assembled, and cut as the strip ( $6 \mathrm{~cm}$ by $4 \mathrm{~mm}$ ) using Matrix 2360-programable shear (Kinematic Automation, USA). The strips were then secured in plastic cassettes. 
Preparation of meat extracts. All processing was conducted at $4{ }^{\circ} \mathrm{C}$ (on ice). One hundred grams of each kind of raw meat (beef, chicken, and pork) was chopped and blended separately in a blender (Rao \& Hsieh, 2007). Each time the blender and the equipment used were cleaned thoroughly to avoid contamination among meat species. After that $10 \mathrm{~g}$ of each blended meat was mixed (1:5 wt/vol) with $50 \mathrm{ml}$ of $0.01 \mathrm{M}$ chilled sodium phosphate buffer containing $0.5 \mathrm{M} \mathrm{NaCl}$ (phosphate-buffered saline, $\mathrm{PB}-\mathrm{NaCl}$ ) for raw meat sample extraction. The mixtures were then blended in a chilled blender for 5 $\min$.

After standing for $30 \mathrm{~min}$ on ice, all the homogenate raw meats, were centrifuged $(3,000 \times g)$ at $4{ }^{\circ} \mathrm{C}$ for 30 min. The supernatants were collected and sodium azide was added to a final concentration of $0.02 \%(\mathrm{v} / \mathrm{v})$. All meat extracts were aliquoted into $1-\mathrm{ml}$ portions in small tubes and stored at $-20{ }^{\circ} \mathrm{C}$ until used.

Preparation of laboratory-adulterated samples. To study the sensitivity of the assay, the meat extract of fresh ground pork was mixed in extract chicken or extract beef samples at 5 final adulteration levels: 1/0; $1 / 100 ; 1 / 1,000 ; 1 / 5,000 ; 1 / 10,000(\mathrm{w} / \mathrm{w})$. The beef or chicken sample containing no pork was included as an unadulterated negative control.

Assay procedure. The IC rapid test was performed by adding a $5 \mu \mathrm{l}$ sample to the loading window (Zone 1, conjugate pad containing goat anti-Swine IgG coupled with gold chloride) of the plastic cassette, followed by adding a $40 \mu \mathrm{l}$ of transport-facilitating agent (running buffer consisted of 1\% Casein in PBS, pH 7.2). The samples are wicked by the membrane from zone 1 into zones 2 and 3 which respectively, are saturated with goat antiSwine IgG and goat-antimouse (GAM) IgG antibodies. Following incubation for $30 \mathrm{~min}$ at room temperature, the membrane was evaluated visually. A single colored line appearing in zone 3 (Figure 1, line A) indicates the absence of pork components. The concurrent presence of colored lines in zones 2 and 3 (Figure 1, line B) indicates the presence of pork components. The absence of line formation (Figure 1, line C) indicates an invalid test that must be repeated. Once the test result has developed, the reaction lines, which form within 2-10 min of sample application, are permanent. Data obtained from the

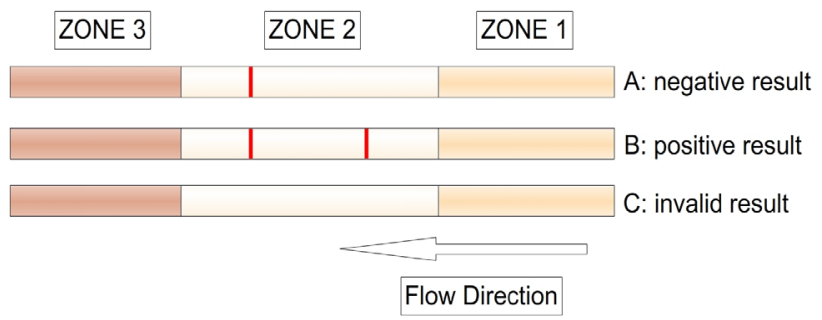

Figure 1. Diagrammatic of immunochromatographic test for pork components in adulterated meats. Zone $1=$ Sample/conjugate pad, Zone $2=$ Nitrocellulose membrane (test zone), Zone $3=$ Absorbance pad. observed variables were analyzed descriptively from six different repetitions assay.

\section{RESULTS AND DISCUSSION}

The results for different levels of laboratoryadulterated samples tested revealed that the IC is successful in detecting very low levels of pork adulteration in raw chicken and beef meat. Table 1 , in accordance with Figure 2, shows the intensity of positive test line increased as the adulteration levels increased in the raw pork-in-chicken or pork-in-beef samples. The detection limit for pork in both raw beef and chicken meat mixtures was determined to be $1 / 5,000(\mathrm{w} / \mathrm{w})$, the lowest adulteration level detected. Although in the level of $1 / 10,000(\mathrm{w} / \mathrm{w})$ the intensity of positive line still can be observed lightly (+/-), which were observed in 2 of 6 replicates or a total of $33.33 \%$ for both in raw beef and chicken meat. For accuracy reason this level should be considered below the level of detection. In general, the detection limit for on-field test purposes, the detection limit of $1 / 5,000$ was acceptable. This acceptability level was more than adequate due to economical considerations and that the mixing of pork or pig components to beef or chicken meat by irresponsible retailers is usually at least $1 / 5$ even $1 / 10(\mathrm{w} / \mathrm{w})$.

Liu et al. (2006) reported that the sandwich ELISA was able to detect $0.05 \%(\mathrm{w} / \mathrm{w})$ of laboratory-adulterated pork in chicken, $0.1 \%(\mathrm{w} / \mathrm{w})$ pork in beef mixtures, $0.05 \%$ $(\mathrm{w} / \mathrm{w})$ pork meal in soy-based feed. When compared with the ELISA developed by Liu et al. (2006) it appears that the IC that we developed in this preliminary study is comparable and even relatively more sensitive.

The present study indicated that immunochromatography rapid test was a reliable technique for detection

Table 1. The cut off level of the IC tests for pork components in adulterated meats

\begin{tabular}{lc}
\hline Sample ratio mix $(\mathrm{w} / \mathrm{w})$ & Colour intensity \\
\hline A. Pork/Chicken & - \\
$0 / 1$ & $+/-$ \\
$1 / 10,000$ & + \\
$1 / 5,000$ & ++ \\
$1 / 1,000$ & ++ \\
$1 / 100$ & +++ \\
$1 / 0$ & \\
B. Pork/Beef & - \\
$0 / 1$ & + - \\
$1 / 10,000$ & + \\
$1 / 5,000$ & ++ \\
$1 / 1,000$ & +++ \\
$1 / 100$ & +++ \\
$1 / 0$ & + \\
\hline Note: $-:$ negative results; $+/-:$ in doubt result; $+:$ positive results; ++ : \\
strong positive results; +++ very strong positive results relative \\
to the control line. $(\mathrm{n}=6)$.
\end{tabular}




\begin{tabular}{|l|l|l|}
\hline IC-PORK-TEST & & Pk/Ch: $1 / 0$ \\
\hline IC-PORK-TEST & & Pk/Ch: $1 / 100$ \\
\hline IC-PORK-TEST & & Pk/Ch: $1 / 1000$ \\
\hline IC-PORK-TEST & & Pk/Ch: $1 / 5000$ \\
\hline IC-PORK-TEST & & Pk/Ch: $1 / 10000$ \\
\hline IC-PORK-TEST & & Pk/Ch: 011 \\
\hline & $\uparrow$ & \\
\hline & T C \\
\hline
\end{tabular}

A

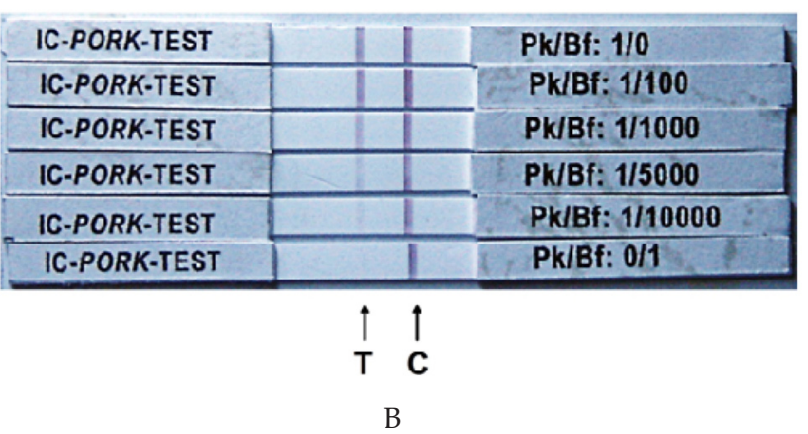

Figure 2. Representative immunochromatography test results for pork components in adulterated raw meats. $\mathrm{Pk} / \mathrm{Ch}=\mathrm{ratio}$ of mixed pork/chicken $($ Panel $\mathrm{A}) ; \mathrm{Pk} / \mathrm{Bf}=$ ratio of mixed pork/beef (Panel B) as outlined in the text; $\mathrm{T}=$ test line; $\mathrm{C}=$ control line; flow direction= left to right.

of pork components in raw beef and chicken meats for halal authentication. However further studies are still needed. The present study was a preliminary study based on laboratory adulterated raw meats. In order to verify practical application of the IC tests, studies need to be expanded using cooked meat as well as processed meats available in the markets.

\section{CONCLUSION}

A rapid immunodiagnostic test to detect low levels of pork components in raw beef and chicken meat products was able to be developed using anti-Swine IgG polyclonal antibody. Assay was completed in $10 \mathrm{~min}$. Detection limit was $1 / 5,000(w / w)$, although $1 / 10,000$ was also observed.

\section{ACKNOWLEDGMENTS}

The research was supported in part by Prof. Mulyanto, Director of West Nusa Tenggara (WNT) Hepatitis Laboratory, Indonesia. Thanks to the Dean of Faculty of Animal Sciences, University of Mataram, Indonesia, to Mr. Hulaimi and Mr. Arif Wahyono, staff of WNT Hepatitis Laboratory for their technical assistances.

\section{REFERENCES}

Aida, A. A., Y. B. Che Man, V. M. V. L. Wong, A. R. Raha, \& R. Son. 2005. Analysis of raw meats and fats of pigs using polymerase chain reaction for halal authentication. Meat Sci. 69: 47-52.

Aida, A. A., Y. B. Che Man, A. R. Raha, \& R. Son. 2007. Detection of pig derivatives in food products for halal authentication by polymerase chain reaction -restriction fragment length polymorphism. J. Sci. Food Agric. 87: 569-572. DOI: 10.1002/jsfa.2699

Asensio, L., I. González, T. García, \& R. Martín. 2008. Determination of food authenticity by enzyme-linked immunosorbent assay (ELISA). Food Control 19: 1-8.

Asero, R., G. Mistrello, \& P. Falagani. 1997. Oral allergy syndrome from pork. Allergy 52:684-686.

Aveyard, J., P. Nolan, \& R. Wilson. 2008. Improving the sensitivity of immunoassays by tuning gold nanoparticles to the tipping point. Anal. Chem. 80: 6001-6005. DOI: 10.1021/ac800699k
Ballin, N. Z., F. K. Vogensen, \& A. H. Karlsson. 2009. Species determination - Can we detect and quantify meat adulteration? Meat Sci. 83:165-174.

Bazin, I., E. Nabais, \& M. Lopez-Ferber. 2010. Rapid visual tests: fast and reliable detection of ochratoxin A. Toxins 2: 2230-2241. doi:10.3390/toxins2092230

Brandonisio, O., L. Fumarola, P. Maggi, R. Cavaliere, R. Spinelli, \& G. Pastore. 2002. Evaluation of a rapid immunochromatographic test for serodiagnosis of visceral leishmaniasis. Eur. J. Clin. Microbiol. Infect. Dis. 21:461-464.

Chen, F-C., Y-H. P. Hsieh, \& R. C. Brigdman. 1998. Monoclonal antibodies to porcine thermal-stable muscle protein for detection of pork in raw and cooked meats. J. Food Sci. 63:201-205.

Ebbehøj, K. F. \& P. D. Thomsen. 1991. Species differentiation of heated meat products by DNA hybridization. Meat Sci. 30:221-234.

Farrokhi, R. \& R. J. Joozan. 2011. Identification of pork genome in commercial meat extracts for Halal authentication by SYBR green I real-time PCR. Int. J. Food Sci. Technol. 46: 951-955. DOI: 10.1111/j.1365-2621.2011.02577.x

Hara, M., S. Takao, S. Fukuda, Y. Shimazu, \& K. Miyazaki. 2008. Evaluation of three immunochromatographic kits for rapid detection of influenza virus $A$ and $B$. LabMedicine 30:603-606. DOI: 10.1309/LM6ONMGY7K9ETMGF

Henderson, K. \& J. A. Stewart. 2000. Dipstick immunoassay to rapidly measure serum oestrone sulphate concentrations in horses. Reprod. Fertil. Dev. 12:183-189.

Hsieh, Y.-H. P., M. A. Johnson, C. J. Wetzstein, \& N. R. Green. 1996. Detection of species adulteration in pork products using agar gel immunodiffusion and enzyme-linked immunosorbent assay. J. Food Qual. 19:1-13.

Jaussen, F. W., G. H. Hagele, A. M. B. Voorpostel, \& J. A. de Baaij. 1990. Myoglobin analysis for determination of beef, pork, horse, sheep and kangaroo meat in blended cooked products. J. Food Sci. 55:1528-1530.

Ketema, F., C. Zeh, D. C. Edelman, R. Saville, \& N. T. Constantine. 2001. Assessment of the performance of a rapid, lateral flow assay for the detection of antibodies to HIV. J. Acquir. Immune Defic. Syndr. 27:63-70.

Khamrin, P., S. Takanashi, W. Chan-it, M. Kobayashi, S. Nishimura, N. Katsumata, S. Okitsu, N. Maneekarn, O. Nishio, \& H. Ushijima. 2009. Immunochromatography test for rapid detection of norovirus in fecal specimens. J. Virol. Methods 157: 219-222.

Kim, H. \& L. A. Shelef. 1986. Characterization and identification of raw beef, pork, chicken and turkey meats by electrophoretic patterns of their sarcoplasmis protein. J. Food Sci. 51:731-735 
Kim, S-H., J-Y. Kim, W. Han, B. Y. Jung, P. D. Chuong, H. Joo, H. V. Ba, W-G. Son, Y. Jee, B-S. Yoon, Y-S. Lee, \& Y-K. Lim. 2007. Development and evaluation of an immunochromatographic assay for screening Listeria spp. in pork and milk. Food Sci. Biotechnol. 16:515-519.

Liu, L., F-C. Chen, J. L. Dorsey, \& Y-H. P. Hsieh. 2006. Sensitive monoclonal antibody-based sandwich ELISA for the detection of porcine skeletal muscle in meat and feed products. J. Food Sci. 71: M1-M6. DOI: 10.1111/j.13652621.2006.tb12393.x.

Macedo-Silva, A., S. F. C. Barbosa, M. G. A. Alkmin, A. J. Vaz, M. Shimokomaki, \& A. Tenuta-Filho. 2000. Hamburger meat identification by dot-ELISA. Meat Sci. 56:189-192.

Matsunaga, T., K. Chikuni, R. Tanabe, S. Muroya, K. Shibata, \& J. Yamada. 1999. A quick and simple method for the identification of meat species and meat products by PCR assay. Meat Sci. 51:143-148.

Ngom, B., Y. Guo, X. Wang \& D. Bi. 2010. Development and application of lateral flow test strip technology for detection of infectious agents and chemical contaminants: a review. Anal. Bioanal. Chem. 397: 1113-1135. DOI:10.1007/s00216-010-3661-4.

Nurjuliana, M., Y. B. Che Man, D. Mat Hashim, \& A. K. S. Mohamed. 2011. Rapid identification of pork for halal authentication using the electronic nose and gas chromatography mass spectrometer with headspace analyzer. Meat Sci. 88:638-44.

Ofori, J. A. \& Y-H. P. Hsieh. 2007. Sandwich enzyme-linked immunosorbent assay for the detection of bovine blood in animal feed. J. Agric. Food Chem. 55:5919-5924. DOI: 10.1021/jf070034r.

Rao, Q. \& Y.-H. P. Hsieh. 2007. Evaluation of a commercial lateral flow feed test for rapid detection of beef and sheep content in raw and cooked meats. Meat Sci. 76:489-494.
Rensen, G. J., W. L. Smith, C. V. Jaravata, B. Osburn, \& J. S. Cullor. 2006. Development and evaluation of a real-time FRET probe based multiplex PCR assay for the detection of prohibited meat and bone meal in cattle feed and feed ingredients. Foodborne. Pathog. Dis. 3:337-46.

Rohman, A., Sismindaria, Y. Erwanto, \& Y. B. Che Man. 2011. Analysis of pork adulteration in beef meatball using Fourier transform infrared (FTIR) spectroscopy. Meat Sci. 88: 91-95. doi:10.1016/j.meatsci.2010.12.007.

Rojas, M., I. González, V. Fajardo, I. Martín, P. E. Hernández, T. García \& R. Martín. 2009. Identification of raw and heat-processed meats from game bird species by polymerase chain reaction-restriction fragment length polymorphism of the mitochondrial D-loop region. Poult. Sci. 88:669-679. doi:10.3382/ps.2008-00261

Rojas, M., I. González, V. Fajardo, I. Martín, P. E. Hernández, T. García \& R. Martín. 2010. Polymerase chain reaction assay for verifying the labeling of meat and commercial meat products from game birds targeting specific sequences from the mitochondrial D-loop region. Poult. Sci. 89:1021-1032. doi:10.3382/ps.2009-00217

Saeed, T., S. G. Ali, H. A. A. Rahman, \& W. N. Sawaya. 1989. Detection of pork lard as adulterants in processed meat: Liquid chromatographic analysis of derivatized triglycerides. J. Assoc. Off. Anal. Chem. 72:921-925.

Wong, R. 2002. The effect of adulterants on urine screen for drugs of abuse: detection by an on-site dipstick device. Am. Clin. Lab. 21:37-39

Yeoh, H. H. \& F. Sun. 2001. Assessing cyanogen content in cassava based food using the enzyme-dipstick method. Food Chem. Toxicol. 39:649-653.

Zhi, A., B. Lia, Q. Liu, X. Hua, D. Zhao, Y. Hou, R. Deng, S-J. Chai, \& G. Zhang. 2010. Development of a lateral-flow immunochromatographic test device for the rapid detection of difloxacin residues. Food Agric. Immunol. 21: 335345. DOI: 10.1080/09540105.2010.504766 